\title{
Prevalence and molecular investigation of caseous lymphadenitis among the slaughtered sheep at Duhok Abattoirs; experimental infection with Corynebacterium pseudotuberculosis in rabbits
}

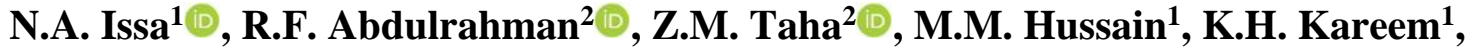 \\ H.I. Hamadamin ${ }^{1}$, Z.D. Najeeb ${ }^{1}$, B.M. Ahmed ${ }^{1}$ and H.M. Hameed $^{1}$ \\ ${ }^{1}$ Surgery and Internal Medicine department, ${ }^{2}$ Pathology and Microbiology Department, College of Veterinary Medicine, \\ University of Duhok, Iraq
}

\begin{tabular}{l} 
Article information \\
\hline Article history: \\
Received March 7, 2020 \\
Accepted April 28, 2020 \\
Available online February 15, 2021 \\
\hline Keywords: \\
Caseous lymphadenitis \\
Sheep \\
Cory. pseudotuberculosis \\
In vivo \\
Rabbits \\
\hline Correspondence: \\
N.A. Issa \\
nawzat.issa@uod.ac
\end{tabular}

\begin{abstract}
Caseous lymphadenitis is a chronic infection caused by Corynebacterium pseudotuberculosis that affects the lymphatic system, resulting in abscesses in the lymph nodes and internal organs. This study was conducted to determine the prevalence rate of caseous lymphadenitis among slaughtered sheep in Duhok abattoirs, Duhok, Iraq and to investigate to what extend rabbits can develop caseous lymphadenitis just like that in sheep. A total of 1052 carcasses of sheep were randomly selected (939 males and 113 females) and carefully inspected for detection any suspected caseous lymph adenitis. The isolated Corynebacterium pseudotuberculosis from lymph nodes of sheep carcasses were identified by PCR before used in in vivo infection in rabbits. Data revealed that the prevalence rate of caseous lymphadenitis was at $1.9 \%$ among the slaughtered sheep and the prevalence rates were higher in females and older ages than that of males and younger ages, respectively. Experimentally infected rabbits developed various clinical signs were ranging from in inappetence to sudden death, mainly during first week of infection. Histopathologically, the infected rabbits developed caseous lymphadenitis and pyogranuloma after a time point of 10 days post-infection. Liver, spleen and lymph nodes of infected rabbits showed caseonecrotic foci with multiple micro-granulomas with presence of thick pyogenic membrane infiltrated with leukocytic cells; these findings are strictly resemblance to that reported in sheep. The obtained preliminary data of using rabbits as an animal model is promising which will enhance a better understanding the pathogenesis of caseous lymphadenitis in animals.
\end{abstract}

DOI: 10.33899/ijvs.2020.126772.1377, (C2021, College of Veterinary Medicine, University of Mosul.

This is an open access article under the CC BY 4.0 license (http://creativecommons.org/licenses/by/4.0/).

\section{Introduction}

Caseous lymphadenitis (CLA) is a chronic, contagious bacterial disease caused by the bacterium Corynebacterium pseudotuberculosis (C. pseudotuberculosis). It is manifested clinically as abscesses of peripheral and/or internal lymph nodes and organs (1). The pus content of the infected lymph nodes is very thick and with no smell (2). Whereas, the peripheral form presents as abscesses of single or multiple peripheral palpable lymph nodes, internal CLA typically 
manifests as chronic weight loss and ill thrift (3). Although prevalence of CLA varies by region and country, it is found worldwide (4). The disease found within two forms, the external which is more common in goats and the enteral form is common in sheep (5). The disease is economically very important and it associates with great economic losses ranging from reduction within the meat and milk productions, damage of carcasses to death (6).

Little evidences are available on the prevalence of the disease among the small ruminant in Iraq; however, the prevalence rate of CAL in sheep was reported in a study among the clinically examined adult sheep in Baghdad at rate of $2.55 \%$ (7), and at $15.12 \%$ in another study by using ELISA (8). Nothing was known on the prevalence rate of the disease among sheep in Duhok area; the effect of the sex and age of infected animals on the prevalence rate of the disease was also unknown.

More studies in depth have been recommended to be conducted to understand the pathogenesis of CLA; the disease is contagious in its nature and its response to the antibacterial antibiotics is poor, besides its control is difficult due to the lack of effective control program (9). The pathogenesis of the diseases in sheep are still not fully understood (10). However, sheep and goats have been used in vivo as animals models to study the immune responses and to evaluate antibacterial activities of some drugs against $C$. pseudotuberculosis $(11,12)$. Guinea pig and mice were also used to study immune responses against Corynebacterium pseudotuberculosis (13), mice were infected with different strains of C. pseudotuberculosis of equine origin for better understanding the clinical signs, microbiological and pathological outcomes of CLA infection $(14,15)$.

Using large animals like sheep and goats as a model to study the pathogenesis of CLA is usually costly and hard to be handling, alternatively, laboratory animals like rabbits are cheap and easily handbill (14). Therefore, the present study was carried out to determine the prevalence rate of the disease among slaughtered sheep in Duhok province and to investigate the potential uses of rabbit as a model for in vivo studies of Corynebacterium pseudotuberculosis infection in rabbits following the oral route.

\section{Materials and methods}

\section{Animals and samples collection}

From September 2019-January 2020, a total of 1052 carcasses of sheep were randomly selected (939 males and 113 females) and inspected at Duhok abattoirs. The carcasses were carefully inspected and any suspected CLA were removed and transported in clean sterile specimen containers (Ayset ${ }^{\circledR}$, Turkey) kept in cold box to the Duhok research Center at the college of Veterinary Medicine, University of Duhok, Iraq for bacterial isolation.

\section{Isolation and Identification of Corynebacterium pseudotuberculosis}

Samples were collected aseptically from the suspected CLA abscessed lymph nodes in order to prevent the contamination from the surface of lymph node and environment. Abscessed lymph nodes were cut using sterile disposable blade and pus were collected and cultured onto $5 \%$ sheep blood agar. The plates were incubated at $37^{\circ} \mathrm{C}$ for 24-48 h. Primary identification was based on standard microbiology methods including Gram stain of pus, colony morphology, and hemolytic activity of the grown bacteria $(16,17)$. Suspected colonies of C. pseudotuberculosis were selected and streaked onto blood agar plate to obtain pure colonies of $C$. pseudotuberculosis. Gram stain and biochemical tests including catalase and urease tests were also used to confirm presumptive identification of $C$. pseudotuberculosis. $50 \%(\mathrm{v} / \mathrm{v})$ glycerol in brain heart infusion broth were prepared and used to store pure cultures of C. pseudotuberculosis at $-20^{\circ} \mathrm{C}$ for further analysis.

The identification of suspected C. pseudotuberculosis isolates were further confirmed by PCR. For DNA extraction, isolates were plated out onto $5 \%$ sheep blood agar from $-20^{\circ} \mathrm{C}$ glycerol stocks and incubated at $37^{\circ} \mathrm{C}$ for $48 \mathrm{~h}$. DNA was extracted using thermal lysis method as described by (18). Briefly, 10 colonies were resuspended in $500 \mu$ l of TAE buffer and mixed very well. Thermal lysis was performed in heating block for 11 to $15 \mathrm{~min}$. The suspension was cooled for $4 \mathrm{~min}$ at $4^{\circ} \mathrm{C}$ then centrifuged at $14,000 \mathrm{~g}$ for 2 min. The supernatant was then used as the DNA template. Prepared DNA was checked for purity using NanoDrop 2000C spectrophotometer (Thermo Scientific/ UK) and kept at $-20^{\circ} \mathrm{C}$ for PCR.

Primers targeting pld gene of C. pseudotuberculosis were obtained from previously published work (19). The pld gene was amplified using a total reaction volume of $20 \mu \mathrm{l}$. Each reaction consisted of $10 \mu \mathrm{l}$ of master mix, $1 \mu$ l of each forward and reverse primer at concentration of $10 \mathrm{pmol}^{-1} \mathrm{l}^{-1}$ (PLD-F: 5'ATAAGCGTAAGCAGGGAGCA'3; PLD-R2: 5’ATCAGCGGTGATTGTCTTCCAGG'3), $2 \mu 1$ of template DNA and $6 \mu 1 \mathrm{dH}_{2} \mathrm{O}$. Reactions were carried out in a Gene Amp PCR System 9700 Thermo Cycler (Applied Biosystems). The following parameters of 40 cycles were used according to (19): initial denaturation at $95^{\circ} \mathrm{C}$ for $3 \mathrm{~min}$, denaturation at $95^{\circ} \mathrm{C}$ for $1 \mathrm{~min}$, annealing at $58^{\circ} \mathrm{C}$ for $40 \mathrm{~s}$, extension at $68{ }^{\circ} \mathrm{C}$ for $90 \mathrm{~s}$ and final extension at $68^{\circ} \mathrm{C}$ for 7 min. Amplification products were separated by electrophoresis on $1 \%(\mathrm{w} / \mathrm{v})$ agarose gel containing Prime Safe Dye (GeNet Bio, Korea). The fragment sizes were visualized under UV light.

\section{Rabbits and inocula preparation for in vivo infection}

Fifteen clinically healthy rabbits at age of two months were purchased from the local markets in Erbil, Iraq, and brought to animals' house at the College of Veterinary Medicine, University of Duhok, Iraq. The rabbits were 
acclimatized to the local environmental condition for a period of a week before conducting the infection experimentally. The rabbits were fed on leafy green vegetables and bread. This study was firstly approved by Animal Ethical Committee at the College of Veterinary Medicine, University of Duhok, Iraq.

\section{Inoculant preparation}

Following molecular confirmation of the isolated Corynebacterium pseudotuberculosis from the CLA of the mediastinal lymph nodes of slaughtered carcasses of sheep, a bacterial suspension as inocula was prepared in brain heart infusion broth (Himedia, India) containing 10\% of sheep serum to enhance the bacterial growth. Inoculated broth was incubated at $37^{\circ} \mathrm{C}$ for $24 \mathrm{~h}$ at 150 revolutions per minute (rpm) in shaker incubator (Stuat, UK). The bacteria were grown to a concentration of approximately $10^{8}$ bacteria per $\mathrm{ml}$ depending on the optical density. The challenge doses of the bacteria $1 \times 10^{7}$ colony forming unit $\mathrm{CFU} / \mathrm{ml}$ were determined using $1 \mathrm{ml}$ of the bacterial suspension which was transferred in a $15 \mathrm{ml}$ centrifuge tube and centrifuged at $1000 \mathrm{x} g$ for $10 \mathrm{~min}$ using macro-centrifuge (Volker, Germany). The supernatant was discarded and the cell pellet was re-suspended in 1\% PBS according to the required challenge dose which was calculated by measuring the optical density of bacterial cultures at $600 \mathrm{~nm}$ by spectrophotometer (Biochrome Ltd, England) and comparing the bacterial CFU number were determined by using the Miles and Misra method (20).

\section{Experimental design}

To detect the potential of developing of CLA in rabbit by the isolated Corynebacterium pseudotuberculosis from sheep, 12 rabbits out of 15 were experimentally infected; the infected rabbits were orally infected with $1 \times 10^{7} \mathrm{CFU} / \mathrm{ml}$. The rest 3 rabbits left non-infected as a control group; the infected and non-infected animals were kept under observation during the period of the experiment (two months).

\section{Post-infection and histopathological changes}

Five rabbits from the infected group were sacrificed after ten days post-infection and their internal organs (lymph nodes, liver and spleen) were removed and cleaned with $1 \%$ PBS for bacterial isolation and for histopathological study using Hematoxylin and Eosin (H\&E) staining protocol. The time point of 10 days post-infection for histopathological study was chosen according to the previous studies $(21,22)$ who found that pyogronulomas in response to Corynebacterium pseudotuberculosis were developed within 10 post experimental infection in goats. For bacterial isolation, the cleaned tissues were weighted firstly and homogenized with an equal amount of $1 \%$ PBS (w/v) in 1.5 $\mathrm{ml}$ standard centrifuge tubes using electric miller (Coyote, China) and followed by two-fold serial dilutions in micro well plates and then cultured on blood agar as mentioned before. For histopathological study, cleaned tissues of the removed organs were fixed in $10 \%$ formaldehyde for a week and then processed with H\&E staining protocol (23-26).

\section{Results}

\section{Prevalence rate of CLA among slaughtered sheep}

The data found that 20 out of 1052 of inspected carcasses of sheep were infected with CLA at prevalence rate $1.9 \%$; among the age groups, the data revealed that the prevalence rates were higher in sheep at age of three years and older than that found in sheep of younger ages. With regards to the gender of the inspected carcasses, the highest rate was reported in females at $10.61 \%$ compared to that in males at $0.85 \%$ (Table 1).

During the carcasses inspection, CLA of the mediastinal lymph nodes were found in variable sizes and contents, the pus was cheesy, creamy -milky to pale green in color as shown in (Figure 1).

Table 1: The prevalence rate of CLA among age and sex groups of slaughtered sheep in Duhok abattoirs

\begin{tabular}{|c|c|c|c|}
\hline \multirow{2}{*}{$\begin{array}{l}\text { Sheep } \\
\text { carcasses }\end{array}$} & \multicolumn{2}{|c|}{ Inspected carcasses } & \multirow{2}{*}{$\begin{array}{l}\text { Prevalence } \\
\text { rate } \%\end{array}$} \\
\hline & Negative & Positive & \\
\hline \multicolumn{4}{|l|}{ Age } \\
\hline$<3$ years & $\begin{array}{c}98.67 \% \\
(740 / 750)\end{array}$ & $\begin{array}{c}1.33 \% \\
(10 / 750)\end{array}$ & $1.33 \%$ \\
\hline$\geq 3$ years & $\begin{array}{c}96.69 \% \\
(292 / 302)\end{array}$ & $\begin{array}{c}3.31 \% \\
(10 / 302)\end{array}$ & $3.31 \%$ \\
\hline \multicolumn{4}{|l|}{ Sex } \\
\hline Males & $\begin{array}{c}99.15 \% \\
(931 / 939)\end{array}$ & $\begin{array}{c}0.85 \% \\
(8 / 939)\end{array}$ & $0.85 \%$ \\
\hline Females & $\begin{array}{c}89.38 \% \\
(101 / 113)\end{array}$ & $\begin{array}{c}10.61 \% \\
(12 / 113)\end{array}$ & $10.61 \%$ \\
\hline
\end{tabular}

\section{Isolation and Identification of $\boldsymbol{C}$. pseudotuberculosis}

Based on colony morphology, Gram staining and biochemical tests all of the grown bacteria were identified as C. pseudotuberculosis; where the colonies on blood agar appeared white, small, dry and non-hemolytic at $24 \mathrm{~h}$ incubation as shown in (Figure 2A). However, after 48 the colonies became pale white to creamy in color, crumbly and surrounded by narrow zone of beta hemolysis as shown in (Figure 2B). Gram stain of the bacterial colonies showed Gram-positive pleomorphic, club-like bacilli as shown in (Figure 2C). Biochemical tests revealed that the isolates were urease and catalase positive.

The isolates were further confirmed by detection of pld gene specific for $C$. pseudotuberculosis. The results showed that DNA fragment of 203 bp for pld gene specific for $C$. pseudotuberculosis was amplified successfully in all samples as shown in (Figure 3). 


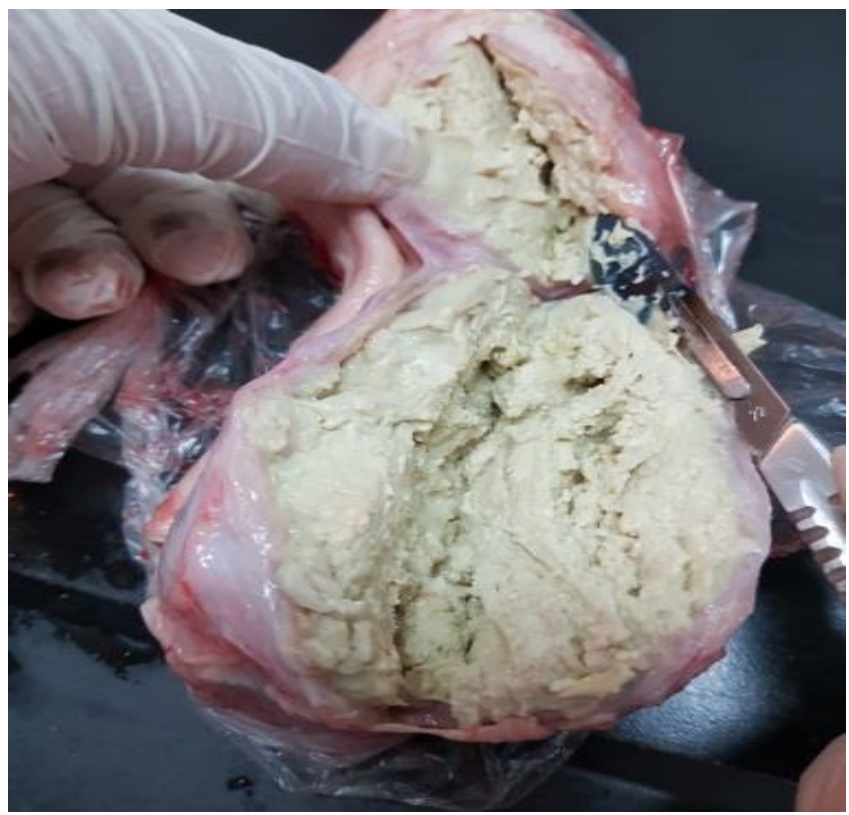

Figure 1: Mediastinal lymph node with caseous abscesses of slaughtered sheep; the abscess was about $7 \mathrm{~cm}$ in diameter contained thick creamy pale green - smell less pus.
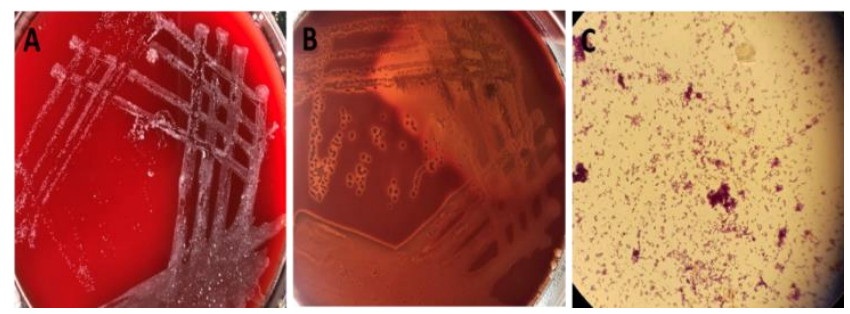

Figure 2: Colony morphology and staining characteristics of C. pseudotuberculosis isolates from mediastinal lymph nodes of slaughtered sheep. Small white, dry and nonhemolytic colonies after $24 \mathrm{~h}$ (A) and colonies surrounded by narrow zone of $\beta$-hemolysis after $48 \mathrm{~h}$ (B). Gram stained smear showed Gram-positive pleomorphic bacilli (C).

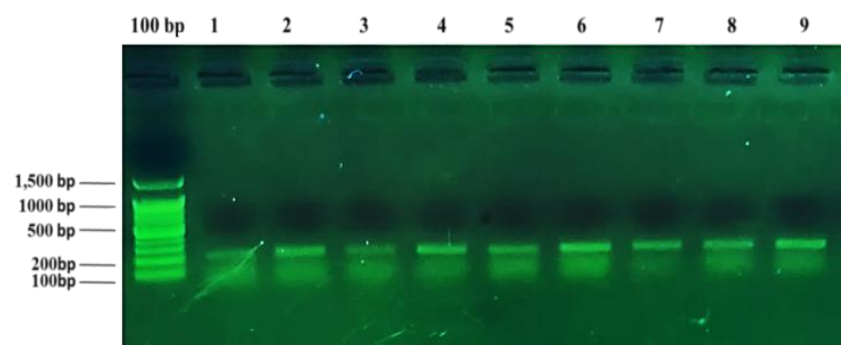

Figure 3: Amplification of the pld gene specific for $C$. pseudotuberculosis isolated from CLA from carcasses of sheep. Lane 100bp: DNA ladder. Lanes 1-9: amplified pld gene in C. pseudotuberculosis isolates.

\section{Clinical signs of experimentally infected rabbits}

Based on daily regular field observations on experimentally infected rabbits and control group, a rabbit was found dead after five days of oral infection. Postmortem inspection on the dead rabbit revealed a clear intestinal congestion, with yellow necrotic foci within the liver (Figure 4). The rest rabbits were suffered from inappetence and lethargy during first week post-infection, but were returned to normal condition and were in good appetite in a week after. Whereas, the control group that were kept under the same environmental condition during the whole period of the experiment were found in good body condition with no any clinical signs compared to the infected group.

At 10 days post-infection, the internal organs (lymph nodes, liver and spleen) of sacrificed rabbits $(\mathrm{N}=5)$ revealed clear enlargement and congestion mainly in spleen and mediastinal lymph nodes, and on the cut surfaces, caseopurulent materials were found in lymph nodes (Figure 5).

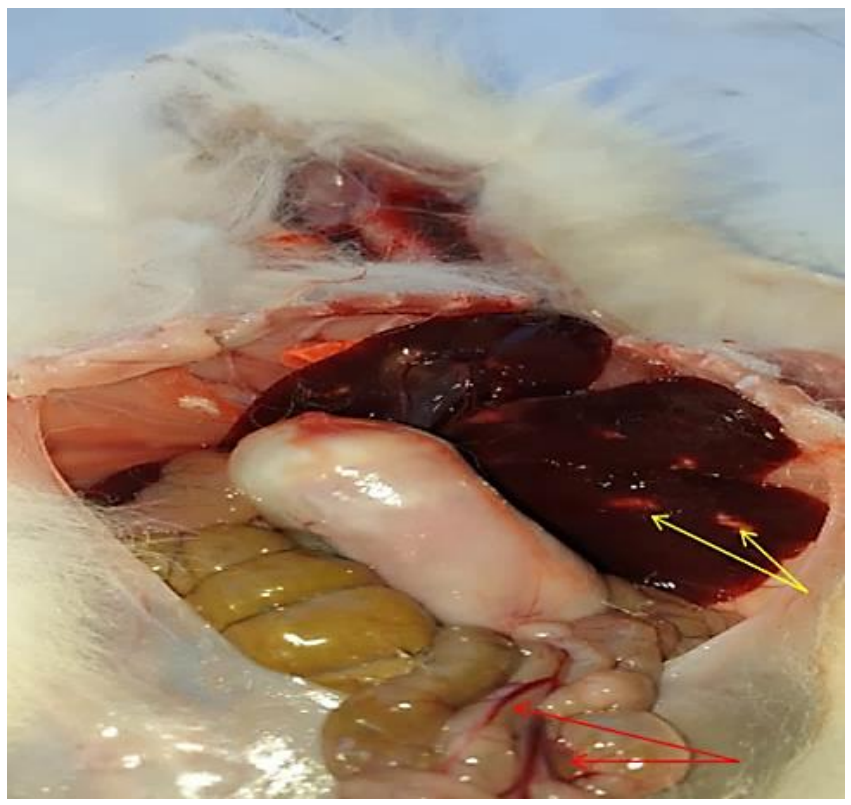

Figure 4: Necrosis lesions (yellow arrows) in liver and congestion (red arrows) in intestine of dead rabbit after 5 day from oral infection with Corynebacterium pseudotuberculosis at $1 \times 10^{7} \mathrm{CFU} / \mathrm{ml}$.

\section{Post-infection bacterial isolation and bacterial loads}

To determine the potential bacterial survival within the bodies of orally infected rabbits, liver, spleen and lymph nodes samples were randomly taken from scarified rabbits at different weight and homogenized then cultured on blood agar. Only three rabbits gave positive bacterial growth; the isolated bacterial CFUs where different between rabbits and between organs (Figure 6). 


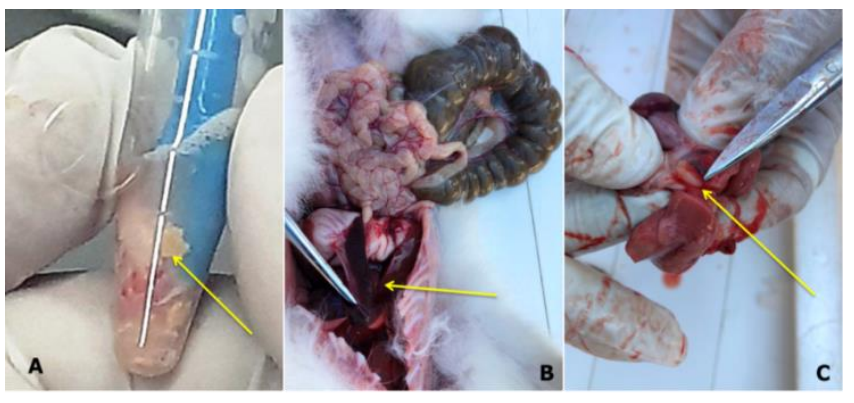

Figure 5: Yellow arrows refer to (A) caseo-purulent materials from crushed lymph nodes by tip of electric miller, (B) prominent enlargement and congestion of liver, (C) enlarged mediastinal lymph node.

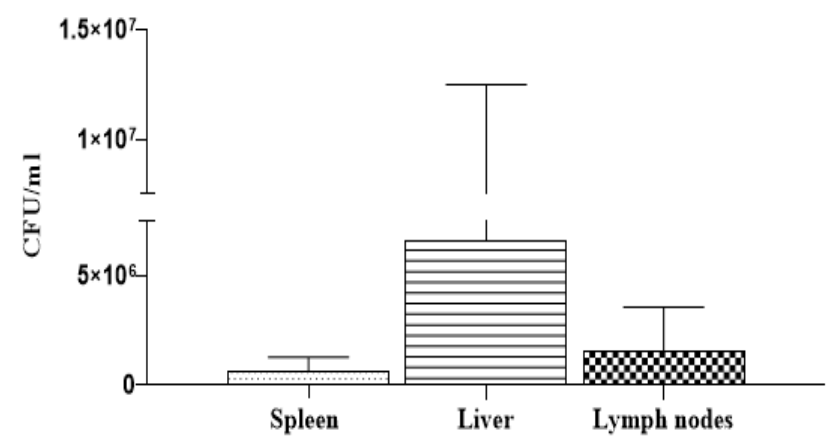

Figure 6: Corynebacterium pseudotuberculosis colony forming unit (CFU)/ $\mathrm{ml}$ retrieved from spleen, liver and lymph nodes samples of infected rabbits after 10 days $(\mathrm{N}=3)$; where the average weights of the used tissues for the bacterial isolation from spleen, liver and lymph nodes were $(0.05 \mathrm{gm}),(0.258 \mathrm{gm})$ and $(0.081 \mathrm{gm})$ respectively.

\section{Histopathological changes}

Histopathologically, Hematoxylin and Eosin stained slides from spleen, liver and lymph nodes samples revealed foci of caseo-necrosis in center with presence of pus and surrounded by clear zones of pyogenic membrane infiltrated with leukocytic cells encapsulated by a thick wall of connective tissue (Figure 7).

\section{Discussion}

The prevalence rate of CLA among sheep in Duhok area and the possibility of using rabbits as a model for in vivo studies on CLA were investigated in this study. The data revealed the prevalence rate of CLA among the slaughtered sheep was at $1.9 \%$ which is in line with that reported among the clinically infected adult sheep in Baghdad at rate $2.55 \%$ (7), and in India at rate $2.31 \%$ (26), in Turkey the prevalence rate of CLA among slaughtered sheep and goats was at $2.2 \%$ based on PCR (27).
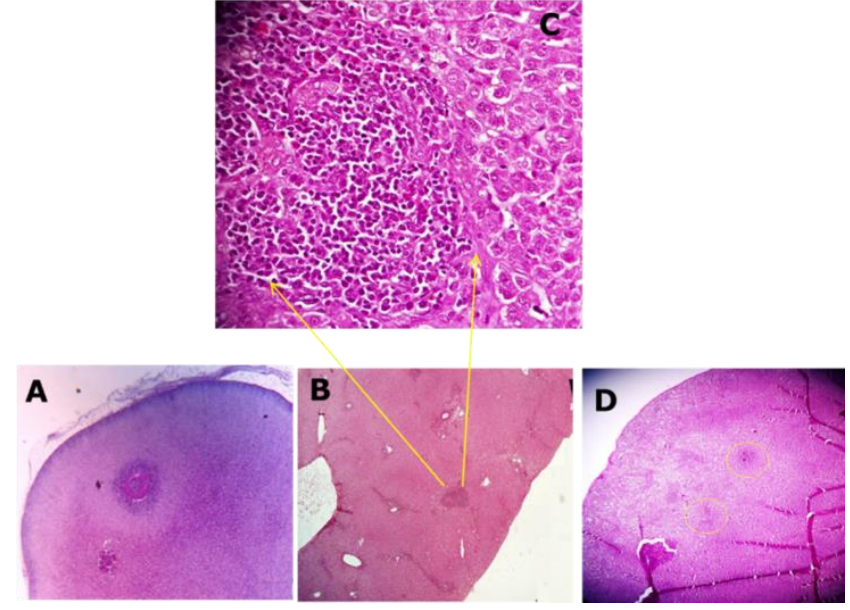

Figure 7: Histopathological lesions of caseous lymphadenitis due to Corynebacterium pseudotuberculosis in infected rabbits after 10 days of experimental infection stained with (H\&E x100). (A) Lymph node with caseated lesions; caseonecrotic center surrounded by a thick pyogenic membrane infiltrated with leukocytic cells. (B) Liver of infected rabbit shows micro caseated lesion, (C) Higher magnification of the liver lesion reveals a high infiltration of leukocytic cells within the core of the abscess with the presence of the bacteria and surrounded by fibrotic cells (connective tissue). (D) Spleen of infected rabbit with caseo-necrotic lesions (yellow ring).

The diagnosis of the suspected CLA was confirmed by laboratory diagnoses, the data revealed that all lymph nodes were positive for $C$. pseudotuberculosis because the primary target site for C. pseudotuberculosis replication is lymph nodes (27). Similar findings have been reported previously in sheep and goats using PCR detection of the bacteria from the lymph nodes by (28) and from lymph nodes of mice by (29). Based on standard microbiology methods including colony characteristics, Gram staining and biochemical tests all isolates showed the characteristics of $C$. pseudotuberculosis as mentioned by $(30,31)$. However, there is variability in characteristics of the species within the Corynebacterium genus; consequently, molecular technique such as PCR technique was developed to confirm the detection of the bacterium. For example, PCR based on $16 \mathrm{~S}$ rRNA, RNA polymerase $\beta$-subunit (rpoB) and phospholipase $\mathrm{D}$ ( $p l d$ ) genes have been developed to identify C. pseudotuberculosis isolates $(19,32)$. In this study, 20 phenotypic suspected isolates were subjected to the PCR using primer targeting specific pld gene of $C$. pseudotuberculosis and the amplification of pld gene of 203 bp showed that $100 \%$ of the tested isolates were positive $C$. pseudotuberculosis. The pld gene encodes the phospholipase D (PLD exotoxin) that implicates in the virulence of $C$. pseudotuberculosis. Detection of C. pseudotuberculosis 
from CLA in sheep and goat based on pld was also confirmed by $(7,19,28)$.

The effect of the risk factors including age and sex of the infected sheep on the prevalence of the disease were determined; the older sheep found higher infection rate of CLA than that of younger ages, these finding are in accordance with that reported by $(8,33)$. The older ages have more chances for exposure to the bacterial infection which escalates the infection rates of CLA (34-36). Increasing infection rate with age probably reflects greater exposure of the animals before slaughtering to risk factors such as shearing and contaminated dipping equipment $(3,37)$, or may be due to animals fighting behavior with transmission through head wounds (38).

With regards to the gender, the data found that prevalence of the disease was higher in female than that of male; the higher rate in females could be due to the age of the animal, where females are kept for longer period than males for reproduction which increase the females exposure to predisposing factors such as shearing and contact with the infected animals (8). This means that ewes usually reared for older ages than rams (34). However, studies found different results (39), the higher susceptibility of the males to the infection could be due to the acute phase protein, mainly haptoglobin which is highly increased in male than that of females in response to Corynebacterium pseudotuberculosis. Increased levels of haptoglobin in sheep in response to the bacteria found to play roles in development of CLA $(39,40)$.

This study was conducted to determine the potential uses of rabbits as a mode for in vivo studying of CLA following detection of the prevalence rate of the disease among the sheep and confirmation of the causative agent. The infected rabbits were clinically characterized by loss of appetite to anorexia, congregated, loss of body condition during first week post-infection, but later the animals returned to its normal appetite. These finding are in accordance with that reported in experimentally infected mice with Corynebacterium pseudotuberculosis (41). Furthermore, the bacteria reproduced CLA, namely in mediastinal and regional lymph nodes similar to that developed in sheep and goats as described (42).

Corynebacterium pseudotuberculosis was isolated after ten days of oral infection from the different organs (spleen, liver and lymph nodes) of infected rabbits at different rates. No study was found on rabbits to compare the present data with; C. pseudotuberculosis biovar ovis strain were isolated after $36 \mathrm{hr}$ post-infection from spleen of mice after intraperitoneally injected with $10^{6} \mathrm{CFU} / \mathrm{ml}$ (43). Besides, four different equine-origin Corynebacterium pseudotuberculosis strains $\mathrm{C} 3 \mathrm{H} / \mathrm{HeJ}$ were isolated from liver, spleen, lungs, and mesenteric lymph nodes of mice following intradermal injection (14). However, these studies used different routes of infection, evidence found that $C$. pseudotuberculosis systemic infection was irrespective of the route of administration in a study was done in guinea
(13). In this study, the bacteria were only recovered from three rabbits, all rabbits were positive histopathologically for the presence of abscess and granulomas; this could be due to the host immune response killed the bacteria $(22,44)$, but could not clear the abscess and the granuloma at the timepoint post-infection which might be due the presence of phospholipase D (PLD) and mycolic acid of the dead bacteria maintained the granuloma development $(15,45)$.

To determine the potential development of CLA and pyogranuloma (in internal organs) in orally infected rabbits after a time point of 10 days post-infection, sections of selected organs were stained with H\&E and evaluated on light microscopy. Caseo-necrotic foci with multiple microgranulomas were found in liver, spleen and lymph nodes; micro-abscesses of caseo-necrotic center surrounded by a thick pyogenic membrane infiltrated with leukocytic cells were found mainly in lymph nodes. These findings are in accordance with that reported in in the lungs, liver and kidneys of orally infected mice with $C$. pseudotuberculosis (15). Microscopically, the granulomas were found within this study were similar to that reported in infected sheep and goats with CLA, where the abscess found with central necrotic area surrounded by pyogenic membrane with infiltration of inflammatory cells $(46,47)$; however, no pathognomonic signs of CLA (onion ring signs) were found in this study, and this could be due to the time point postinfection where relayed in this study was not enough to develop the lamellate lymphadenitis which is chronic and needs time to be developed (48).

\section{Conclusions}

Taken together, the study found that the disease is prevalent among the sheep within the area; molecular and histopathological studies are recommended to be conducted for larger scales researches to determine the prevalence of the disease among the different areas of Duhok province. Preliminary data revealed that using of rabbits as an animal model to study pathogenesis of CLA is promising; further studies are recommended to be done, namely with regards to the interactions between the host and the pathogen in terms of immune response, to validate the potential uses of the animal for in vivo studies.

\section{Acknowledgments}

The authors would like to thank Collage of Veterinary Medicine staff for their supports and providing us with the required facilities to carry out this research work. Thanks to director of Duhok abattoir for providing facilities to collect samples from animals.

\section{Conflict of Interest}

No conflict of interest. 


\section{References}

1. Piotr L, Gryzińska M, Marcin M, Stephen P, Albrecht B, Malgorzata D. Caseous lymphadenitis in sheep in the falkland islands. Acta Vet Brno 2016;66(3):406-412. Doi: $10.1515 /$ acve-2016-0034

2. Washburn KE, Fajt VR, Lawhon SD, Adams LG, Tell LA, Bissett WT. Caprine abscess model of tulathromycin concentrations in interstitial fluid from tissue chambers inoculated with Corynebacterium pseudotuberculosis following subcutaneous or intrachamber administration. Antimicrob Agents Chemother. 2013;57(12):62956304. Doi: $10.1128 /$ AAC.00936-13

3. Williamson LH. Caseous lymphadenitis in small ruminants. Vet Clin North Am Food Anim Pract. 2001;17(2):1-5. Doi: 10.1016/S07490720(15)30033-5

4. Minozzi G, Mattiello S, Grosso L, Crepaldi P, Chessa S, Pagnacco G. First insights in the genetics of caseous lymphadenitis in goats. Ital J Anim Sci. 2016;16(1):31-38. Doi: 10.1080/1828051X.2016.1250610

5. Ranjithkumar M, Kamili NM, Saravanan M, Shivakumar MU, Dey S. Caseous lymphadenitis in a goat. Indian Vet J. 2012;89(2):66-67. Doi: 10.1111/j.1751-0813.1934.tb01036.x

6. Sood NK, Sandhu BS, Gupta K, Narang D, Vasudeva K, Singh ND. Mesenteric caseous lymphadenitis in a cow calf caused by Corynebacterium pseudotuberculosis: A case report. Vet Med. 2012;57(7):371-375. Doi: 10.17221/6266-VETMED

7. Al-badrawi TYG and Habasha FG. Bacteriological and Molecular Studies of Ovine Caseous lymphadenitis in Iraq. J Agri Vet Sci. 2016;9:46-51. Doi: 10.9790/2380-0905024651

8. Ghazi Habasha F and Yassin Ghani Al-Badrawi T. Serological detection of caseous lymphadenitis in sheep using elisa in and outside Baghdad. Bas J Vet Res. 2016;15:208-213. [available here]

9. Abebe D, Sisay TT. Determination of Corynebacterium pseudotuberculosis prevalence and antimicrobial susceptibility pattern of isolates from lymph nodes of sheep and goats at an organic export abattoir, Modjo, Ethiopia. Lett Appl Microbiol. 2015;61(5):469-476. Doi: 10.1111/lam.12482

10. Othman AM, Abba Y, Jesse FFA, Ilyasu YM, Saharee AA, Haron AW. Reproductive pathological changes associated with experimental subchronic Corynebacterium pseudotuberculosis infection in nonpregnant boer does. J Pathol. 2016;2016:1-7. Doi: $10.1155 / 2016 / 4624509$

11. Santiago LB, Pinheiro RR, Alves FSF, Santos VWS dos, Rodrigues A de S, Lima AMC. In vivo evaluation of antiseptics and disinfectants on control of caseous lymphadenitis: Clinical, haematological, serological and microbiological monitoring. Arq Inst Biol. 2013;80(3):273-280. Doi: 10.1590/s1808-16572013000300003

12. Mahmood ZKH, Jesse FF, Saharee AA, Jasni S, Yusoff R, Wahid H. Clinio-pathological changes in goats challenged with corynebacterium peudotuberculosis and its exotoxin (PLD). Am J Anim Vet Sci. 2015;10(3):112-132. Doi: 10.3844/ajavsp.2015.112.132

13. Vaid J. Immune Responses to Corynebacterium pseudotuberculosis [PhD thesis]. Surrey: University of Surrey; 1988. [available here]

14. Nieto NC, Foley JE, MacLachlan NJ, Yuan T, Spier SJ. Evaluation of hepatic disease in mice following intradermal inoculation with Corynebacterium pseudotuberculosis. Am J Vet Res. 2009;70(2):257262. Doi: $10.2460 / a j v r .70 .2 .257$

15. Latif NAA, Abdullah FFJ, Othman AM, Rina A, Chung ELT, ZamriSaad M. Isolation and detection of Corynebacterium pseudotuberculosis in the reproductive organs and associated lymph nodes of non-pregnant does experimentally inoculated through intradermal route in chronic form. Vet World. 2015;8(7):924-927. Doi: 10.14202/vetworld.2015.924-927

16. Hussein SA. Study of Staphylococcus aureus isolated from the mouth of canary. Iraqi J Vet Sci. 2020;34(2):301-304. Doi: 10.33899/ijvs.2019.125937.1192

17. Assafi MS, Hado HA, Abdulrahman IS. Detection of methicillinresistant Staphylococcus aureus in broiler and broilers farm workers in duhok, Iraq by using conventional and PCR techniques. Iraqi J Vet Sci. 2020;34(1):15-22. Doi: 10.33899/ijvs.2019.125757.1145
18. da Conceição Aquino de Sá M, Gouveia GV, da Costa Krewer C, Veschi JLA, de Mattos-Guaraldi AL, da Costa MM. Distribution of PLD and FagA, B, C and D genes in Corynebacterium pseudotuberculosis isolates from sheep and goats with caseus lymphadenitis. Genet Mol Biol. 2013;36(2):265-268. Doi: 10.1590/S1415-47572013005000013

19. Pacheco LGC, Pena RR, Castro TLP, Dorella FA, Bahia RC, Carminati R. Multiplex PCR assay for identification of Corynebacterium pseudotuberculosis from pure cultures and for rapid detection of this pathogen in clinical samples. J Med Microbiol. 2007;56(4):480-486. Doi: $10.1099 / \mathrm{jmm} \cdot 0.46997-0$

20. Miles AA, Misra SS, Irwin JO. The estimation of the bactericidal power of the blood. J Hyg. 1938;38(6):732-749. Doi: 10.1017/S002217240001158X

21. Pépin M, Seow HF, Corner L, Rothel JS, Hodgson ALM, Wood PR. Cytokine gene expression in sheep following experimental infection with various strains of Corynebacterium pseudotuberculosis differing in virulence. Vet Res. 1997;28(2):149-63. Doi: 10.1016/S09284249(97)85253-4

22. Aroch I, Harmelin A, Saran A, Levin D, Shpigel NY. Experimental Corynebacterium pseudotuberculosis mastitis in dairy cows. Vet Rec. 2003;153(24):746-750. Doi: 10.1136/vr.153.24.746

23. Al-Jammas S, Al-Saraj A. The histological changes induced by cytarabine on rabbits kidneys (with and without vitamin e administration). Iraqi J Vet Sci. 2019;33(2):311-316. Doi: 10.33899/ijvs.2019.162910

24. Al-Hamdany MZ. Comparative anatomical, histological, and histochemical study of liver in human and domestic rabbit. Iraqi J Vet Sci. 2019;33(2):437-446. Doi: 10.33899/ijvs.2019.163193

25. Cardiff RD, Miller CH, Munn RJ. Manual hematoxylin and eosin staining of mouse tissue sections. Cold Spring Harb Protoc. 2014;10:27. Doi: $10.1101 / \mathrm{pdb}$.prot073411

26. Kumar J, Tripathi BN, Kumar R, Sonawane GG, Dixit SK. Rapid detection of Corynebacterium pseudotuberculosis in clinical samples from sheep. Trop Anim Health Prod. 2013;45(6):1429-1435. Doi: 10.1007/s11250-013-0381-8

27. Cetinkaya B, Karahan M, Atil E, Kalin R, De Baere T, Vaneechoutte M. Identification of Corynebacterium pseudotuberculosis isolates from sheep and goats by PCR. Vet Microbiol. 2002;88(1):75-83. Doi: 10.1016/s0378-1135(02)00089-5

28. Guerrero JAV, de Oca Jiménez RM, Acosta Dibarrat J, León FH, Morales-Erasto V, Salazar HGM. Isolation and molecular characterization of Corynebacterium pseudotuberculosis from sheep and goats in Mexico. Microb Pathog. 2018;117:304-309. Doi: 10.1016/j.micpath.2018.02.031

29. Jesse FF, Adamu L, Osman AY, Muhdi AF Bin, Haron AW, Saharee AA. Polymerase chain reaction detection of c. pseudotuberculosis in the brain of mice following oral inoculation. Int $\mathbf{J}$ Anim Vet Adv. 2013;5(1):29-33. Doi: 10.19026/ijava.5.5571

30. Dorella FA, Pacheco LGC, Oliveira SC, Miyoshi A, Azevedo V. Corynebacterium pseudotuberculosis: Microbiology, biochemical properties, pathogenesis and molecular studies of virulence. Vet Res. 2006;37(2):201-218. Doi: 10.1051/vetres:2005056

31. Alves JRA, de Farias AE, dos Anjos, DM. Seroepidemiological study of caseous lymphadenitis in sheep from the Northeast region of Brazil using an indirect ELISA. Trop Anim Health Prod. 2020;52:1945-1952. Doi: https://doi.org/10.1007/s11250-020-02214-9

32. Khamis A, Raoult D, La Scola B. rpoB gene sequencing for identification of Corynebacterium species. J Clin Microbiol. 2004;24(9):3925-3931. Doi: 10.1128/JCM.42.9.3925-3931.2004

33. Kaba J, Nowicki M, Frymus T, Nowicka D, Witkowski L, SzaluśJordanow O. Evaluation of the risk factors influencing the spread of caseous lymphadenitis in goat herds. Pol J Vet Sci. 2011;14(2):231237. Doi: $10.2478 / \mathrm{v} 10181-011-0035-6$

34. Al-Gaabary MH, Osman SA, Oreiby AF. Caseous lymphadenitis in sheep and goats: Clinical, epidemiological and preventive studies. Small Rumin Res. 2009;87(1-3):116-121. Doi: $\underline{10.1016 / j . s m a l l r u m r e s .2009 .10 .008}$ 
35. Chikhaoui M and Khoudja FB. Clinicopathological investigation on caseous lymphadenitis in local breed sheep in Algeria. Trop Anim Health Prod. 2013;45(7):1641-3. Doi: 10.1007/s11250-013-0410-7

36. Ali A, Mahmoud A, Khadr A, Elshemey T, Abdelrahman A. Corynebacterium Pseudotuberculosis: Disease prevalence, lesion distribution, diagnostic comparison through microbiological culture and molecular diagnosis. Alexandria J Vet Sci. 2016;51(2):189-198. Doi: 10.5455/ajvs.219993

37. Baird GJ, Fontaine MC. Corynebacterium pseudotuberculosis and its Role in Ovine caseous lymphadenitis. J Comp Pathol. 2007;137(4):179210. Doi: $10.1016 /$ j.jcpa.2007.07.002

38. Nomi BS. Investigation for bacterial causes of superficial abscesses in Iraqi goats. 2016;15:51-53. Doi: 10.29079/vol15iss1art369

39. Jeber ZKH, MohdJin Z, Jesse FF, Saharee AA, Sabri J, Yusoff R. Influence of Corynebacterium pseudotuberculosis infection on level of acute phase proteins in goats. BMC Vet Res. 2016;12:48. Doi: $\underline{10.1186 / s 12917-016-0675-\mathrm{y}}$

40. Eckersall PD, Lawson FP, Bence L, Waterston MM, Lang TL, Donachie W. Acute phase protein response in an experimental model of ovine caseous lymphadenitis. BMC Vet Res. 2007;3:35. Doi: $\underline{10.1186 / 1746-6148-3-35}$

41. Othman AM, Abba Y, Jesse FFA, Ilyasu YM, Saharee AA, Haron AW. Reproductive pathological changes associated with experimental subchronic Corynebacterium pseudotuberculosis infection in nonpregnant boer does. J Pathol. 2016;1-7. Doi: 10.1155/2016/4624509

42. Pépin M, Pardon P, Lantier F, Marly J, Levieux D, Lamand M. Experimental Corynebacterium pseudotuberculosis infection in lambs: Kinetics of bacterial dissemination and inflammation. Vet Microbiol. 1991;26:381-392 Doi: 10.1016/0378-1135(91)90031-A

43. Silva WM, Dorella FA, Soares SC, Souza GHMF, Castro TLP, Seyffert N. A shift in the virulence potential of Corynebacterium pseudotuberculosis biovar ovis after passage in a murine host demonstrated through comparative proteomics. BMC Microbiol. 2017;17:55. Doi: 10.1186/s12866-017-0925-6

44. Simmons CP, Dunstan SJ, Jachedjian M, Krywult J, Hodgson ALM, Strugnell RA. Vaccine potential of attenuated mutants of Corynebacterium pseudotuberculosis in sheep. Infect Immun. 1998;66(2):474-9. Doi: 10.1128/IAI.66.2.474-479

45. Khuder Z. Sex hormone profiles and cellular changes of reproductive organs of mice experimentally infected with C. pseudotuberculosis and its exotoxin phospholipase D (PLD). IOSR J Agric Vet Sci. 2012;1(3):24-29. Doi: $10.9790 / 2380-0132429$

46. Mira C, Fatima BK, Fadhela S, Kada K, Yacine T. Epidemiological and Histopathological Studies on caseous lymphadenitis in slaughtered goats in Algeria. Glob Vet. 2014;13:1065-1068. Doi: 10.5829/idosi.gv.2014.13.06.9182

47. Zavoshti FR, Khoojine ABS, Helan JA. Frequency of caseous lymphadenitis (CLA) in sheep slaughtered in an abattoir in Tabriz: Comparison of bacterial culture and pathological study. Comp Clin Pathol. Doi: 2012;21:667-671. Doi: 10.1007/s00580-010-1154-7

48. Fontaine MC, Baird GJ. Caseous lymphadenitis. Small Rumin Res. 2008;76(s1-2):42-48. Doi: 10.1016/j.smallrumres.2007.12.025

\section{الانتشار والتحري الجزيئي لالتهاب العقد اللمفية

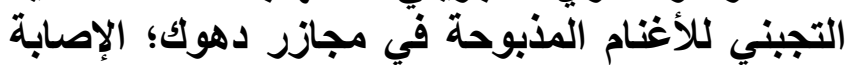 التجريبية بجراثيم السل الكاذب في الأرانب فئب}

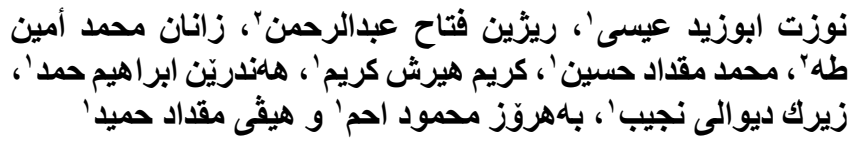

نوزت ابوزيد عيسى'، ريزين فتاح عبدالرحمن'، زانان محمد أمين

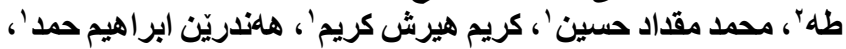

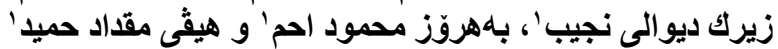

' فرع الطب الباطني والجراحة، ` فرع الأمر اض و الأحياء المجهرية، كلية الطب البيطري، جامعة دهوك، العراق البرات

الخلاصة

يعد التهاب العقد اللمفية التجبني من الأمر اض المزمنة التي تسببها

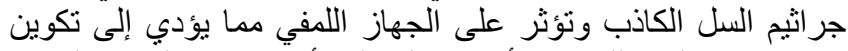

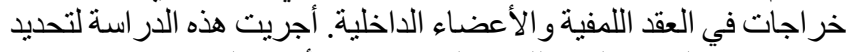
مدى انتشار التهاب العقد اللمفية التجبني في الأغنام المذبوحة في مجازية إناءر

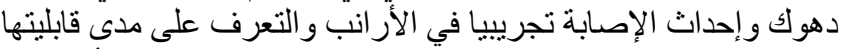

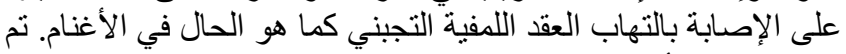

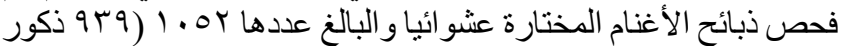

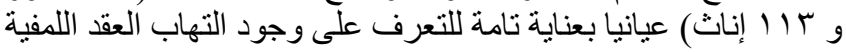
التجبني. تم التعرف على جراثيم السل الكاذب في العقد اللمفية لذبائح

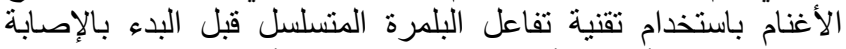

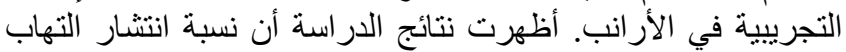

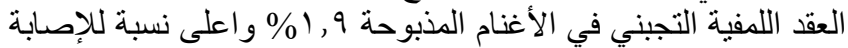
تم تسجيلها في الإناث والحيوانات المتقدمة بالعمر مقارنة بالأكور

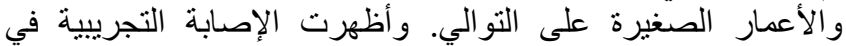

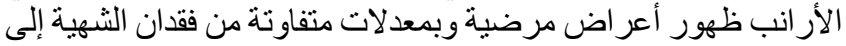

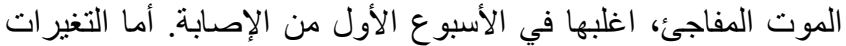

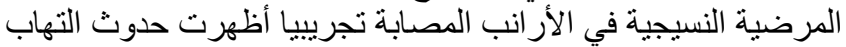

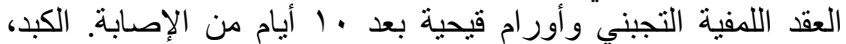

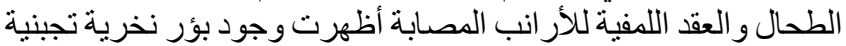
و أورام صغيرة متعددة مع وجود قيح وارتشاحات للخلايا البيضاء.

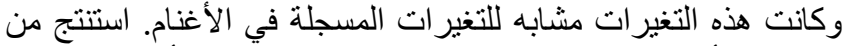

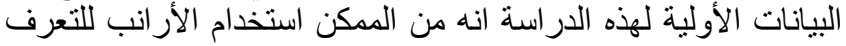

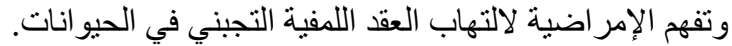

